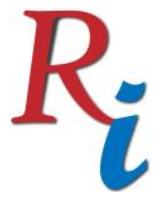

\title{
DEVElOPMENT OF A PACKAGE PRINT MODULES FOR CHRISTIAN RELIGIOUS EDUCATION Jhoni Lagun Siang*
}

Departement of Education Mathemathic Bumi Hijrah University Indonesia

\author{
Lambertus J. Lokollo
}

Departement of Education PattimuraUniversity

Indonesia

\section{Rasmin Simbolon}

Departement of Educational Technology

Medan State University

Indonesai

*Corrosponding author's Email: jhonilagunsiang@unibrah.ac.id

Author's Biography

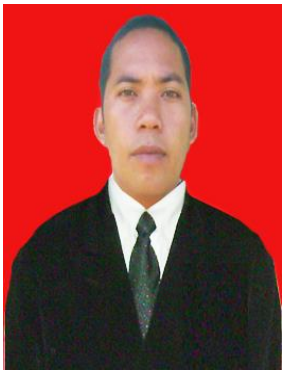

Jhoni Lagun Siang, is a lecturer at Bumi Hijrah University. Born in Togola Sangir, June 14, 1979, was the second child of the late Mr. Lorens Lagunsiang and Ms. Alce Masihor. Obtained a Bachelor's degree in the Philosophy Department of Religion, Klabat University, Manado. S1 Department of Religion Education, Klabat University, Manado. Postgraduate Program in Educational Technology, Jakarta State University and currently while completing a doctoral program (S3) in Education Technology Study Program at the Postgraduate of Jakarta State University.

The teaching career of the writer began when he was appointed as the Eklesia Jailolo Vocational School from 2008-2009. Teaching at the Akediri Advent Middle School from 20092010. In 2010 he taught at the City 11 Tidore Islands Public Middle School from 2010 until now. Married to Junivke Susana Kaseger, from the marriage the author was blessed with one son named Joynivly Lagunsiang and two daughters named Lovely Lagunsiang and Velove Sabathiny Lagunsiang.

Books that have been written include: 1) Modules of Junior High School Class VIII Christian Education subject matter, 2) Student modules in class VIII Junior High School Christian Education, 3) books become professional teachers in the digital era and 4) book strategies, methods and model of teaching a sabbath school. Besides that, a lot of doing research and writing in national / international journals. Actively participating in national / international seminars, conferences and workshops. Several national seminars that have been attended as speakers / speakers. And also active in church activities. 


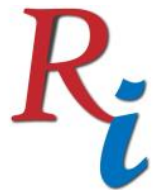

Asia Proceedings of Social Sciences

(APSS)

www.readersinsight.net/APSS

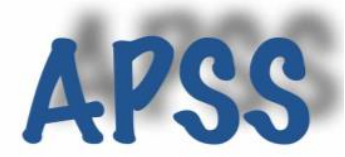

\section{Re search H i g h I igh t s}

The purpose of this research is to produce a learning module of Christian education for students of SMP class VIII. The methodology used is research and development method. In the development using the Derek Rowntree model consisting of three stages, namely the planning stage, preparation phase of writing, and the stage of writing and editing. The product test phase begins with the validation of the material expert, and the media expert. Then after repaired the product was tested to a number of grade VIII students, ie 3 students for individual evaluation and 30 people for field evaluation. The results show the average value of material experts 3.77 which means the product is considered very good and from media experts 3.78 which means the product is considered very good. Then in the trial stage the average yield for the individual test phase 3.63 which means the product is considered very good and at this stage the field trials test 3.98 is considered very good. Based on interviews to teachers obtained very good results. In conclusion the print module of Christianity education subject of SMP Negeri Kota Tidore Kepulauan is worthy to be used in the field, although there are some improvements according to expert advice, students as users, and teachers.

Keyword: Research Development, Rowntree Models, Module.

\section{Research Objectives}

Education that should be felt and enjoyed by every Indonesian citizen in North Maluku who still cannot be felt evenly. This resulted in a decline in the quality of education from year to year. Although not all regions have declined, this has made the quality of education in North Maluku uneven.

The reality of education in North Maluku including, on small islands or inland areas there are many inadequate qualities of education both from teaching staff or staff, educational facilities and infrastructure, textbooks, including Christian religious education textbooks. The school has never provided a handbook for students.

For this reason, it is necessary to develop learning resources in the form of a Print Module subject to Christian Education that can enable students to learn to achieve learning goals. Development of learning resources can be in the form of learning packages that are arranged systematically and systematically because they are validated by experts, as well asevaluations one-to-one, and field tests.

\section{Methodology}

The approach taken in this study is the approach to developing product-oriented learning and using the Rowntree development model. This approach is carried out because this research begins by examining the problem by analyzing learning needs in schools to determine whether or not the module package can help in the learning process.

This study aims to produce a product in the form of a learning module for Christian Education in SMP Negeri Kota Tidore Kepulauan. Packaged in a printed form that can be used for independent learning. Judging from the goal of developing a product, this research can be said as researchand development.

Methodologically this research uses a research approach through Derek Rowntree's research and development procedures. Research and development methods are methods used to produce certain products, and test the effectiveness of these products. Development research aims to find, develop and validate a product. 


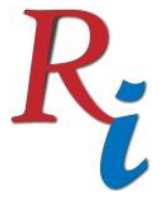

\section{Asia Proceedings of Social Sciences \\ (APSS) \\ www.readersinsight.net/APSS}

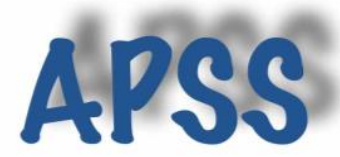

The product developed was trialled in three stages, the trial phase, face to face trials, and trial field trials. The product testing phase begins with a trial of material and media experts. Then the product was tested to a number of class VIII students, namely 3 people for the face to face tryout stage and 30 people for the field trial evaluation stage.

\section{Results}

Results of the study showed the average score obtained at the expert trial stage as follows. The average score of the material expert is 3.77 which means the product is considered good and the media expert is 3.78 which means the product is very good. Then in the stage of testing to students the average score for the face to face tryout stage is 3.63 which means the product is considered very good and at the field trial evaluation stage is 3.98 which means the product is considered very good. The results of the interviews with the teacher obtained very good results. In conclusion, the print module of the Tidore Islands City Middle School Christian Education subject for grade VIII students can be said to be good but still needs improvement in accordance with expert advice, students as users, and teachers.

\section{Findings}

Module print subjects Christian education SMP Negeri 11 Tidore Islands developed already very well and should be maintained, but still there is a component modules that need to be repaired and dikembagkan terms of four feasibility and the effectiveness test conducted as follows:

According to the subject matter expert (expert matter), the print module of junior high school Christian education subjects is in a very good category, In terms of content, the feasibility of the feasibility of presentation and feasibility of language according to material experts has been very good.

Meanwhile, according to expert media, the module developed was in the good category According to media experts all module components are complete, the module size is appropriate and the visual message design principle is very good.

According to the Christian education teacher, this module falls into the very good category.

According to students, this junior high school Christian education print module is a very good category.

Overall, it can be concluded that the print module of the Christian Religious Education in Tidore Islands Middle School in the Middle School is in a very good category, where the module is feasible and effective to use.

\section{Acknowledgement}

This research was sponsored by a powerful God who gave blessings in the form of health, strength and finance so that this research could work well

\section{References}

Rowntree Derek. (1994). Preparing Materials for Open, Distance, and Flexible Learning. London: Kogan Page. Smaldino Sharon E, Debora L.Lowther, James D Russel. (2008). Instructional Technology and Media for Learning. New Jersey: Pearson Prentice Hall. 